International Journal of Research in Business and Social Science IJRBS

ISSN : $2147-4478$

Vol.4 No.2, 2015

www.ssbfnet.com/ojs

\title{
A Survey of Managerial Perspective on Corporate Dividend Policy: Evidence from Turkish Listed Firms
}

\section{Narman Kuzucu}

Assistant Professor, Istanbul Medipol University

34810, Beykoz, Istanbul, Turkey,

+902166815100

\begin{abstract}
This research paper examines the corporate dividend payout behaviors of non-financial firms from Istanbul Stock Exchange (Borsa Istanbul). Survey method is conducted to investigate managerial views on corporate dividend policy. The study investigates whether the evidence in Turkish stock market on dividend policy is similar to the European and the U.S. firms' results which are reported earlier by other studies, and moreover in what extent Lintner's (1956) findings on dividends is supported by today's listed firms in an emerging market. The financial managers from 38 firms out of 216 non-financial companies responded the survey. The results show that there is a significant positive relationship between cash dividends and earnings. Earnings are viewed as the most important factor in dividend decision like in European and the U.S. firms. Sustainable change in earnings, stability and level of future earnings, and the desire to distribute a proportion of earnings to shareholders are the common determinants of dividend policy. The majority of the respondents reports that they target dividends. Dividend yield is the most common measure for dividend targeting. Share repurchases are not viewed as alternative to dividend payouts unlike the U.S. firms. The study finds supporting evidences for bird-in-the-hand and signaling hypotheses, and Lintner's model.
\end{abstract}

Key words: Dividend policy; Share Repurchase; Borsa Istanbul; Managerial Perspective

JEL code: $\mathrm{O} 16$

\section{Introduction}

Dividends and dividend policy have been among the key research areas in finance theory. Starting from the Modigliani and Miller's (1961) irrelevance theorem, dividends have been a controversial issue. The effect of dividends on firm value became a core topic around dividends with Modigliani and Miller's (MM) model. The assumptions of irrelevance model inspired the other models which seek to explain dividends, such as taxeffect hypothesis (Brennan, 1970), clientele effects (Elton and Gruber, 1970; Miller and Scholes, 1978), agency costs (Jensen and Meckling, 1976), signalling hypothesis (Ross, 1977; Bhattacharya, 1979; Miller and Rock, 1985), and behavioural explanations (Shefrin and Statman, 1984; Shefrin and Thaler, 1988).

Recently, researches on dividends have been focused on corporate payout behaviours more than the relevancy of dividends and the effects of market imperfections on dividends for a couple of decades. Fama and French (2001), DeAngelo, DeAngelo and Skinner (2004), Baker and Wurgler (2004) investigated whether dividends disappeared, reappeared or concentrated and 
how the firm specific characters affect dividend behaviours. Baker, Farrelly and Edelman (1985), Baker and Powell (1999, 2000), Da Silva, Goergen and Renneboog (2004), Brav, Graham, Harvey and Michaely (2005), Bancel, Bhattacharyya and Mittoo (2005), and Denis and Osobov (2008) examined the determinants of dividend payout policy, particularly using surveys on managerial perspectives. Those researches emphasized on the cross-country, legal system and other specific characteristics of firms on dividend decisions. Empirical evidence is obtained from managerial perspective in most of those researches. Dong, Robinson and Veld (2005), Grinstein and Michaely (2005), and Graham and Kumar (2006) focused on investors' preferences on dividends. They examined the effect of clienteles, retail versus institutional investors. All of those researches try to explain the motives and the reasons underlying dividend decisions. Focusing on why and how firms pay out dividends has been a research approach in dividends literature to explain the payout behaviours.

The objective of this study is to examine corporate dividend policies of firms and the factors which influence dividends, focusing on Turkish listed firms. The study investigates that how the corporate managers make dividend decisions and what are the approaches and the opinions of managers towards dividends.

\section{Literature Review}

In a recent survey (Baker, Singleton and Veit, 2011) in which the finance academics were questioned with 144 valid responses, dividend policy was ranked in the sixth out of twenty corporate finance subjects that would most benefit from future survey research. ${ }^{1}$ The survey reports that finance academics believe in that survey research in finance produces data unavailable from other sources, and helps bridge the gap between the theory and practice.

Survey technique on dividend policy was initiated with the pioneering work in this field literally. Lintner (1956) who founded the modern understanding of dividend policy conducted surveys and detailed interviews with the managers of 28 listed companies on NYSE.

Baker, Farrelly, and Edelman (1985) surveyed CFOs of 318 NYSE-listed firms (in a sample of 562 selected firms), asking which factors they consider most important in determining their firm's dividend policy.

\footnotetext{
I The highest rankings are corporate governance, capital budgeting, risk measurement and management, behavioral finance and capital structure, respectively.
}

Their main purpose was to compare their evidence with Lintner's findings 30 years earlier. Furthermore, one of their purposes was to determine the effect of industry on managers' views about the determinants of dividend policy. The industry groups were utility, manufacturing, and wholesale/retail. The results showed that the most ranked determinants were the anticipated level of future earnings and the pattern of past dividends, and the availability of cash holdings, respectively. The first two factors were consistent with Lintner's findings. In the second part of the survey, the financial managers were asked whether they agreed in some statements about dividend policy. The results also supported Lintner's findings as the two statements were among highest ranked statements that a firm should avoid making changes in its dividend rates that might soon have to be reversed, and should try to maintain a stable track record of dividend payments. Moreover, managers agreed in that they targeted dividend payouts. Dividend patterns of regulated industries such as utilities are different than the others. Baker et al. (1985) reported that utilities industry had apparently higher payout ratios than the other ones. Regulations may be a significant factor on dividends. Thus, they propose that highly regulated industries should be separately examined from competitive industries.

Pruitt and Gitman (1991) surveyed 1,000 largest US firms' managers about investment, financing and dividend policies. Their results suggest that dividends are closely related to earnings. The main determinants are current and past years' earnings, variability of earnings and growth in earnings. Their results are consistent with Lintner's findings, and the survey results of Baker et al. (1985).

Baker and Powell (2000) examined the views of financial managers about the determinants of dividend policy with a similar questionnaire 15 years later than Baker et al. (1985). Their work had 258 respondents out of a sample set including 603 NYSE-listed firms. The results are nearly the same with a more limited scope. They reported that little change occurred in the views of managers on dividend policy after 15 years. The most ranked factors were the level of current and expected future earnings, and pattern of past dividends.

Baker, Powell, and Veit (2002) surveyed the financial managers NASDAQ firms. They included the financial sectors firms unlike the similar works, and compared the dividend patterns of those to non-financial firms. They examined the managers' views, analyzing the data of 188 respondents out of 630 sample firms. The highest ranked factors were the pattern of past 
dividends, the stability of earnings, and the level of current and expected future earnings, respectively. These results are consistent with earlier survey studies of NYSE-listed firms. They compared the results of financial firms' managers to non-financial counterparts, and found significant differences between the overall rankings of two clusters. Accordingly, respondents from financial firms view the most ranked factors more important than their non-financial counterparts. Concerns about target capital structure and financial leverage are of more importance from the perspective of financial firms' managers. Moreover, "legal rules and constraints" were rated more significantly as a more important factor for financial firms. Financial firms and banks must meet some specific capital adequacy requirements. Thus, regulated sectors such as banks are more concerned with the legal rules and constraints.

Brav, Graham, Harvey and Michaely "BGHM" (2005) conducted a survey on 384 financial managers and additionally interviews with 23 managers to determine the dividend and share repurchase policies of both public and private (mostly public) non-financial firms in the US. They found that Lintner's key findings are still valid for corporate payout decisions. Firms smooth dividends from year to year as Lintner proposed. Firms are reluctant to cut dividends since market reacts to dividend decreases. On the other hand, firms are reluctant to initiate or increase dividends because of concerns about earnings' stability in the future. Their results diverge in dividend targeting of Lintner's model. They propose that firms target the dividend payout ratio less than they used to in the past. Large share repurchases replaced the dividends and managers favor the flexibility of share repurchases. Their results indicate that managers think that operational and investment decisions are more important than financing decisions. This is clearly consistent with MM's irrelevance theory. Surveyed managers' views do not support clientele explanations whereas they provide evidence for that tax is one of the dominant factors of dividend payouts.

Bancel, Bhattacharyya and Mittoo "BBM" (2005) surveyed managers from 16 European countries to examine cross-country determinants of payout policy. ${ }^{3}$

\footnotetext{
${ }^{2}$ The surveys of Brav et al. (2005) and Bancel et al. (2005) are used as benchmarks for this study. Therefore, the initials of the authors, BGHM and BBM are used as acronyms in the paper for simplicity.

${ }^{3}$ The surveyed firms are of Austria, Belgium, Denmark, Finland, France, Germany, Greece, Ireland, Italy, the Netherlands, Norway, Portugal, Spain, Sweden, Switzerland, and the United Kingdom.
}

Additionally, one of their research purposes was to collect managerial data about European repurchases and to compare with the US counterparts, noting that repurchases were prohibited in certain European countries up until lately and most firms also continued to pay regular dividends beside repurchase unlike the US.

They find that managerial views of European firms on the factors which influence dividend decisions are largely similar to the US peers. Lintner's findings are supported also by European mangers' views. Moreover, European managers' views on the determinants of share repurchases are similar to their peers in the US.

European countries have different legal systems; mainly, Civil law, Common law and Scandinavian law. Cross-country results of managerial views on dividends do not show a systematic relation between quality of legal systems and dividend policies. Thus, the results of BBM do not support La Porta, Lopez-De-Silanes, Shleifer and Vishny (2000) who proposed a positive relation between legal protection of investors and dividend policies.

Dong, Robinson, and Veld (2005) conducted a survey on individual investors to investigate why investors want dividends. They asked questions about personal finance and consumption patterns to more than 2,000 individual investors in the Netherlands. The questionnaire was designed to test the evidence for various theories and explanations of dividend policy. The results obtained through investors' responses to the questions regarding the consumption and cash dividends do not support behavioural explanations. However the responses on stock dividends are consistent with behavioural explanations.

Baker, Dutta and Saadi (2008) surveyed Canadian listed firms at Toronto Stock Exchange. They examined the views of both financial and non-financial firms' managers. They investigated the effect of financial and multinational operations on dividends from managerial perspective. The most rated factors are the stability of earnings, the pattern of past dividends, the level of current earnings, and the level of expected future earnings, respectively. They result that financial and non-financial firms differs in many aspects. Nonfinancial firms' managers agree more with the view that dividends generally follow a smoother path than earnings whereas managers of financial firms agree in that a firm must set a target dividend payout ratio more significantly. Baker et al. (2008) compare their results to the surveys by BGHM and by BBM, and result that the most important determinants of dividends perceived by 
Canadian firms' managers are similar to those of US and European firms.

Researchers used similar questionnaires to survey corporate managers in different countries including European, Middle East, Japan and South Asia countries. This study is one of the first researches (maybe the first) which focus on the managerial perspective of Turkish listed firms as far as we know.

\section{Research and Methodology}

A survey research was conducted to obtain the opinions of financial managers on dividend policies of Turkish listed companies. Questionnaire based studies in corporate finance focus particularly on developed markets such as American and European countries. Emerging markets are rarely the target of survey researches on corporate finance. The target of this study is the listed companies in Turkish stock market (Borsa Istanbul or BIST). The objective of the research is determining the factors influencing the dividends and the dividend decisions of Turkish listed firms by examining the finance executives' opinions on dividends. In the end, the findings are compared to previous works done for the European and US firms.

\section{Survey Design and Hypotheses}

The survey questionnaire includes several questions on dividends and share repurchases that have been used in the studies of BGHM (2005) and BBM (2005). Those questionnaires were adapted to Turkey conditions, particularly considering the tax and share repurchase regulations differences. Similar questionnaires were used to investigate the managerial views in various countries by different researchers. This provides a base for comparative analysis of cross-country dividend policies.

Survey method has some limitations. Surveys measure perceptions and the views of the respondents. Those may differ from the actual corporate actions. Actually, this is not a problem for the study because the goal is indeed to investigate managerial perspective.

Surveys may suffer from non-respondent bias. Nonresponse bias usually cannot be avoided and thus, inevitably creates statistical measurement errors at most survey researches. In order to minimize nonresponse, confidential / private questions which corporate managers may hesitate to respond or answer correctly were not included in the questionnaire during the design of the survey. Furthermore, representativeness of the data of respondents was tested to detect nonresponse bias.
In order to determine possibility of non-response bias, the responding firms were compared to non-responding firms. Some firm characteristics of the 38 respondent firms were compared to the sample set including both respondents and non-respondents. Table 1 exhibits the summary statistics of respondents and the sample set. No significant differences exist between the respondent and non-respondent firms on the compared characteristics. The test results show that the sample set of respondent firms is quite representative to the whole sample set. Thus, non-response bias does not appear to be a considerable problem in the survey.

The questionnaire has mainly two sections. In the first section, six closed-end questions are available. The first question in which sixteen factors exist is related to the determinants influencing dividend decision. The second question has eighteen statements. The respondents are asked to answer how the factors / statements regarding the dividend payouts suit their company's dividend policies. Five-point scaling which measures (-2) as unimportant / strongly disagree to (2) as very important / strongly agree is used. The third question is about dividend targeting with multiple choices. The remaining three questions are about the managers' opinions regarding share repurchase which is a new practice for Turkish companies brought by the new commercial code. In the second section of the questionnaire, the managers were asked about the profiles of their firms like size, industry and ownership structures in order to provide data for cross-sectional analysis. The survey was designed as a web-based survey and submitted to the corporate executives as a link to the survey. The questionnaire takes totally 10 - 15 minutes to complete.

The survey hypothesizes that the stability and level of future earnings, and sustainable change in earnings are the major determinants of dividends as they are such in the European and the US corporate managers' opinions. Therefore, the first hypothesis of the survey is the views of Turkish and European firms' managers on dividend payout policy are influenced by similar factors. The results of the survey will enable us to view the similarities and dissimilarities of the motives behind dividend policy of listed firms on BIST compared to European peers. Thus, following hypotheses are examined:

$\mathrm{H}_{1 \mathrm{a}}$ : The factors influencing dividends of Turkish listed firms are similar to European firms based on their financial managers' views.

$\mathrm{H}_{1 \mathrm{~b}}$ : The views of Turkish and European financial managers are similar on their firms' dividend policy. 
Share repurchase is a new tool for firms in Turkish stock market. Another objective of the survey research is to learn what drives share repurchase decision of a firm in place of dividend payout, and how the financial managers view the new tool. The prior studies show that share repurchases are considered as substitutes for dividends by the US firms whereas majority of European firms considers as a tool for flexibility rather than substitutes for dividends (BGHM, 2005: BBM, 2005).

In European managers' perspective, the major factor influencing share repurchase decision is stock price (BBM, 2005). The undervaluation of the share price of the firm will trigger share repurchase decision rather than a dividend payment. Therefore, the second hypothesis of the survey is as follows:

$\mathrm{H}_{2}$ : Turkish and European managers' views on share repurchase decision are influenced by similar factors.

\section{Sample Set}

The number of listed firms was 240 on BIST, excluding the financial sector companies as of year 2012 when the survey was conducted. Financial firms such as banks, insurance companies, holdings, leasing and factoring companies are excluded from the scope because their financing sources and capital structures are very different from the non-financial firms. Thus, the number of companies in the sample set which were invited to participate in the survey was finally, 216, taking into account those treasury operations and shareholder / investor relations of some groups of companies were shared.

The invitation e-mails including the survey's web address was sent to the CFOs on February 2012. Some required measures were taken to avoid duplication in responses. The firms which did not fill out the questionnaire were reminded one month later and once again on May 2012. The questionnaire was submitted to the remaining firms once again by facsimile or an attached spreadsheet file in an e-mail to the managers who asked at last on October 2012 in order to increase the response rate. Finally, 38 valid responses were obtained from BIST-listed companies with a response rate of $17.6 \%$. It is a relatively favorable result when response rates of similar surveys have been considered. For instance, the survey which was conducted by BBM for European firms had a response rate of 8.2\%. BGHM obtained $16 \%$ response rate in their survey for the US firms whereas the response rate was $35.4 \%$ in a survey for Canadian listed firms by Baker et al (2008). The answerers were mostly CFOs, then treasurers, finance and accounting managers and rarely investor relation managers of the associated firms, respectively.

Table 1 exhibits the characteristics of respondent firms in comparison with the sample set. Initially, sample set and respondents are grouped as dividend payers and non-payers. A firm which has paid out at least once for the last three years is assumed to be a payer. Subsequently, the firms are classified in terms of size, industry, ownership and floating rate. The sales revenue in the year 2011 was taken into account.

$23.7 \%$ of respondent firms have smaller sales revenue than 100 million TL. The sales of $44.7 \%$ of the respondent firms are between 100 million TL and 1 billion TL. $31.6 \%$ of the respondents are large size firms with sales greater than 1 billion TL. Firms are divided into manufacturing and non-manufacturing groups by industry. Accordingly, $63.2 \%$ of respondent firms are manufacturing, and $36.8 \%$ of them are nonmanufacturing whereas $71.3 \%$ of the firms in the sample set are manufacturing, and $28.7 \%$ of the sample set is non-manufacturing firms. Turkish listed firms are generally family or individual controlled firms. In the sample set, $62.5 \%$ of the firms are family controlled. Similarly, $63.2 \%$ of the respondents are family controlled firms whereas the remaining $36.8 \%$ is widely held. The distribution of respondent firms by size, industry and ownership is quiet similar to the distribution of the firms in the sample set.

The firms are grouped by floating rate as less than $20 \%$, between $20 \%$ and $39 \%$, and greater than $40 \%$. Accordingly, the breakdown of respondents into these groups is $28.9 \%, 52.6 \%$, and $18.4 \%$ respectively. The breakdown of the firms in the sample set is not much different; $33.3 \%, 41.2 \%$, and $25.5 \%$, respectively.

$45.4 \%$ of the firms in the sample set have paid out dividends at least once in the last three years. The firms which hold this criterion are supposed to be a dividend payer. The remaining portion of $54.6 \%$ is not payer, accordingly. $60.5 \%$ of the respondents are dividend payer. That shows dividend payer firms are more likely to participate in the survey. The executives of payer firms are more interested in a survey research on dividends. 
Table 1: Summary Statistics of Sample Set and the Respondents

\begin{tabular}{|c|c|c|c|c|}
\hline Comparison by Size & $\begin{array}{l}\text { \# of Sample } \\
\text { Firms }\end{array}$ & $\begin{array}{c}\% \text { of Sample } \\
\text { Firms }\end{array}$ & $\begin{array}{l}\text { \# of Respondent } \\
\text { Firms }\end{array}$ & $\begin{array}{c}\% \text { of Respondent } \\
\text { Firms }\end{array}$ \\
\hline \multicolumn{5}{|l|}{ Small (Sales less than $100 \mathrm{~m}$} \\
\hline TL) & 70 & $32.4 \%$ & 9 & $23.7 \%$ \\
\hline Medium (Sales between $100 \mathrm{~m}$ & & & & \\
\hline TL - 1bn TL) & 106 & $49.1 \%$ & 17 & $44.7 \%$ \\
\hline \multicolumn{5}{|l|}{ Large (Sales greater than 1 bn } \\
\hline TL) & 40 & $18.5 \%$ & 12 & $31.6 \%$ \\
\hline TOTAL & 216 & $100.0 \%$ & 38 & $100.0 \%$ \\
\hline \multicolumn{5}{|l|}{ Comparison by Industry } \\
\hline Manufacturing & 154 & $71.3 \%$ & 24 & $63.2 \%$ \\
\hline \multicolumn{5}{|l|}{ Non-manufacturing (service / } \\
\hline trade) & 62 & $28.7 \%$ & 14 & $36.8 \%$ \\
\hline TOTAL & 216 & $100.0 \%$ & 38 & $100.0 \%$ \\
\hline \multicolumn{5}{|l|}{ Comparison by Ownership } \\
\hline $\begin{array}{l}\text { Family } \quad(\text { or } \quad \text { individual }) \\
\text { controlled }\end{array}$ & 135 & $62.5 \%$ & 24 & $63.2 \%$ \\
\hline Widely held & 81 & $37.5 \%$ & 14 & $36.8 \%$ \\
\hline TOTAL & 216 & $100.0 \%$ & 38 & $100.0 \%$ \\
\hline \multicolumn{5}{|l|}{ Comparison by Floating Rate } \\
\hline Less than $\% 20$ & 72 & $33.3 \%$ & 11 & $28.9 \%$ \\
\hline Between $\% 20$ and $\% 39$ & 89 & $41.2 \%$ & 20 & $52.6 \%$ \\
\hline Greater than $\% 40$ & 55 & $25.5 \%$ & 7 & $18.4 \%$ \\
\hline TOTAL & 216 & $100.0 \%$ & 38 & $100.0 \%$ \\
\hline \multicolumn{5}{|l|}{ Comparison by Payouts } \\
\hline Payer & 98 & $45.4 \%$ & 22 & $57.9 \%$ \\
\hline Non-payer & 118 & $54.6 \%$ & 17 & $42.1 \%$ \\
\hline TOTAL & 216 & $100.0 \%$ & 38 & $100.0 \%$ \\
\hline
\end{tabular}

Source: Author

\section{Results and Discussions}

Table 2 exhibits the Spearman's ranking correlation coefficients between the firm specific variables of respondent firms. Spearman's correlation coefficients measure the correlation of the corporate variables used in the survey analysis. The coefficients are quit low. These results show that there is no evidence of multicollinearity between the firm-level variables in the cross-sectional regression analysis.
The correlation coefficients of dividend variable with various variables exhibit noteworthy results. Dividend variable's (DIV) correlation coefficients with size, leverage are statistically significant at the $5 \%$ level, and with EPS at the $1 \%$ level. The sign of correlation coefficients with EPS (.703) and Size (.341) are positive whereas the one with $\mathrm{D} / \mathrm{A}$ (.331) is negative. Accordingly, dividend payouts are positively correlated to earnings and size; and negatively correlated to leverage. 
Narman Kuzucu /International Journal of Research in Business and Social Science

Vol 4, No 2, 2015 ISSN: $2147-4478$

Table 2: Summary Statistics of Sample Spearman's Rank Correlation Coefficients

\begin{tabular}{|c|c|c|c|c|c|c|c|c|c|c|c|}
\hline VARIABLES & Size & Ind & Exp & For & Flo & 0wn & DIV & $\mathrm{D} / \mathrm{A}$ & $\mathrm{P} / \mathrm{B}$ & $\mathrm{P} / \mathrm{E}$ & EPS \\
\hline \multicolumn{12}{|l|}{ Size } \\
\hline \multicolumn{12}{|l|}{ Sig. (2-ataled) } \\
\hline \multirow{2}{*}{$\begin{array}{l}\text { Ind } \\
\text { Sigg. (2-talled) }\end{array}$} & .266 & 1.0 & & & & & & & & & \\
\hline & .107 & & & & & & & & & & \\
\hline \multirow{2}{*}{$\begin{array}{l}\text { Exp } \\
\text { Sig.(2-ailed) }\end{array}$} & -0.015 & $.483^{* * *}$ & 1.0 & & & & & & & & \\
\hline & .930 & .002 & & & & & & & & & \\
\hline \multirow{2}{*}{$\begin{array}{l}\text { For } \\
\text { Sig. (2-talled) }\end{array}$} & -.238 & .200 & .109 & 1.0 & & & & & & & \\
\hline & .150 & .229 & .515 & & & & & & & & \\
\hline \multirow{2}{*}{$\begin{array}{l}\text { Flo } \\
\text { Sig. (2-ataled) }\end{array}$} & .093 & -036 & .197 & .116 & 1.0 & & & & & & \\
\hline & .578 & .832 & .236 & .488 & & & & & & & \\
\hline \multirow{2}{*}{$\begin{array}{l}0 \text { wn } \\
\text { Sig.(2-tailed) } \\
\end{array}$} & .072 & .178 & .008 & .179 & -241 & 1.0 & & & & & \\
\hline & .668 & .284 & .963 & .283 & .145 & & & & & & \\
\hline \multirow{2}{*}{ Sig (2-tailed) } & $.341^{*}$ & .053 & -209 & .245 & .035 & .204 & 1.0 & & & & \\
\hline & .036 & .753 & .207 & .138 & .834 & .219 & & & & & \\
\hline \multirow{2}{*}{$\begin{array}{l}\mathrm{D} / \mathrm{A} \\
\mathrm{Sig} \text { (2-tailed) }\end{array}$} & .314 & -0.040 & .096 & .152 & .165 & .005 & $-331^{*}$ & 1.0 & & & \\
\hline & .055 & .812 & .568 & .363 & .321 & .977 & .042 & & & & \\
\hline \multirow{2}{*}{$\begin{array}{l}\text { PIB } \\
\text { Sig. (2-atiled) }\end{array}$} & .266 & -.159 & .240 & $-331^{*}$ & .026 & .193 & .304 & .268 & 1.0 & & \\
\hline & .117 & .354 & .159 & .048 & .881 & .260 & .072 & .114 & & & \\
\hline \multirow{2}{*}{$\begin{array}{l}\mathrm{P} / \mathrm{E} \\
\text { Sig. (2-taliled) }\end{array}$} & .103 & -.122 & .008 & .054 & .077 & .100 & .129 & .169 & .352 & 1.0 & \\
\hline & .600 & .536 & .969 & .785 & .697 & .614 & .512 & .390 & .072 & & \\
\hline \multirow{2}{*}{\begin{tabular}{|l|} 
EPS \\
Sig. (2-tailed)
\end{tabular}} & $.437^{* *}$ & .146 & -001 & $-322^{*}$ & .137 & .049 & $.703^{* *}$ & .178 & $.425^{* *}$ & .090 & 1.0 \\
\hline & .006 & .382 & .994 & .044 & .412 & .772 & .000 & .284 & .010 & .651 & \\
\hline
\end{tabular}

Cross tabulations are conducted by surveveded firms' characcteristics. These are Size, where large firms are defined as those companies with reported sales exceeding 1 billion TL; Industry (Ind), where the firm is manufacturing of non-manufacturing, foreign sales (Exp), where a firms forign sales exceeds 25\% of total sales; foriegn shares (For), wher the foreign shareholders own more than 20\% of total common stocks; floating rate (Fl), where the shares exceeding 20\% of the shares of the company are traded at the Stock Exchange; ownership (Own), denoting whether the firm is family controlled or not; payout ratio (DIV), denoning whether the firm has paid dividend at least once in the last 3 years of not; l leverage $(D / A)$, where a high debtt toata lassets ratio is defined as exceeding 0.50; price-to-book ratio (PB), where the price-to-book ratio is greater than 2; PE, where the price-to-earnings ratio is greater than 14; $\mathrm{EPS}$, where a profitable firm is defined having EPS $>$. The variables are ranked from low to high. The values at first rows for each variable denote correlation cofficients while the second rows show pvalues. ** and * denote significance at the $1 \%$ and $5 \%$ levels, respectively.

Peer-reviewed Academic Jourral published by SSBFNET with ressect to copyright holders. 
Corporate financial managers are asked several questions to explore what factors influence the companies' dividend policies and how the companies' payout policies and practices are in the view of financial executives.

Table 3 shows the results of responses for each of the factors influencing the respondent firms' dividend policy. The factors are ranked by the average rating in the table. Column 2 reports the percentage of respondents considering a factor as important or very important. Column 3 provides the mean rating. Column 4 shows whether the mean rating is significantly different from zero on the basis of a ttest. For comparison, columns from 5 to 8 provide the views of CFOs from Europe and the USA on the related factors from the surveys of BBM (2005) and BGHM (2005).

The results of T-statistic tests indicate that all the factors are significant in dividend decision except three factors. These three insignificant factors are; need to keep minority shareholders happy, attracting institutional investors, and the market price of firm's stock. The influence of institutional shareholders is significant at the $10 \%$ level. Reducing cash disciplines firms to make efficient decisions is significant at the $5 \%$ level. The other ten factors are significant at the $1 \%$ level.

Cross-sectional regression tests were made to examine the strength of the relation between the rankings of factors of dividends by firm specific factors. The fivepoint scales are collapsed into three categories; strongly disagree and disagree ( -2 and -1$)$, neither agree nor disagree (0), and agree and strongly agree $(+1$ and +2$)$ in order to perform these tests and to compare the results with the results of prior surveys for Europe and the U.S.

\subsection{The Factors Influencing Dividend Decisions}

Table 3 presents the responses of financial managers in regards with the factors influencing dividend payout decisions. The most important factors according to the ranking by average ratings are; desire to pay out a given fraction of earnings in the long run $\left(\mathrm{F}^{4}\right.$; mean rating: 1.13), a sustainable change in earnings ( $\mathrm{F}$; 1.05 ), and current degree of financial leverage (F6; 1.05), respectively. The fourth factor is (F2) stability and level of future earnings with the mean rating of 1.03. The other factors are of less importance relatively with average ratings decreasing from 0.70 to -0.87 .

The ranking of the factors is slightly different when the percentages of responses of important and very important $(+1$ and +2$)$ are considered in place of the mean rating. A great majority of respondents think ( $84 \%$ for each) that a sustainable change in earnings (F1), stability and level of future earnings (F2) are the most important factors in dividend decisions. Desire to pay out a given fraction of earnings in the long run (F3) is the third factor. $82 \%$ of the respondents view that desire to pay out a given fraction of earnings in the long run is important in dividend decision. These results strongly agree with the Lintner Model which suggests dividends are related to company earnings, and firms have a long-run desired payout ratio between dividends and earnings (Lintner, 1956). Moreover, these results are very similar to the ones of European survey by BBM in 2005. The ranking of the first three factors are the same with the opinions of CFOs from European firms. 
Narman Kizucu /International Journal of Research in Business and Social Science

$$
\text { Vol 4, No 2, } 2015 \text { ISSN: 2147-4478 }
$$

Table 3: Responses to the Factors Influencing Dividend Payout Decisions

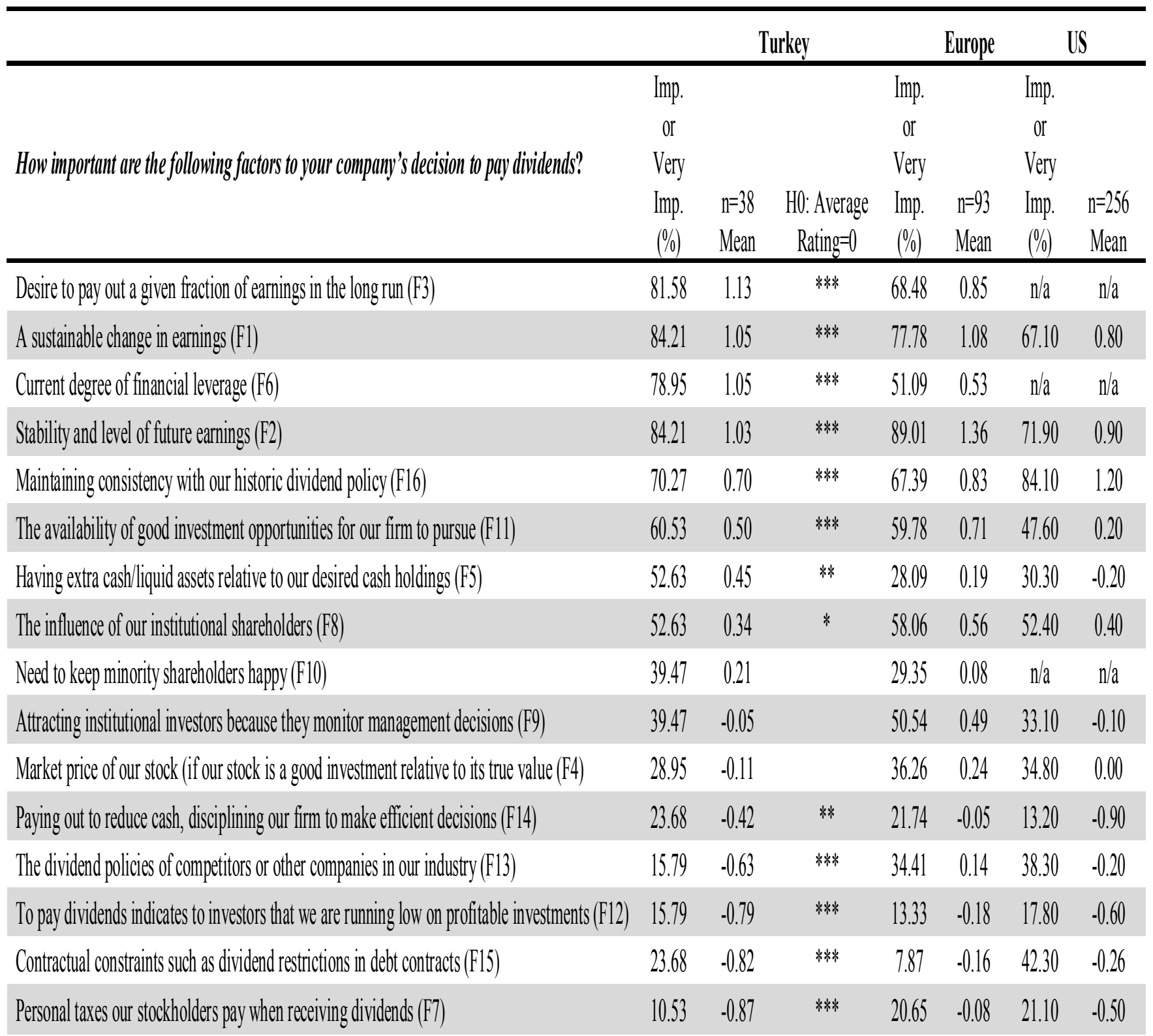

Column 1 lists each of the 16 factors rated by the respondents. Column 2 shows the percentage of responses of important $(+1)$ and very important $(+2)$. Column 3 shows the mean rating of each factor. Column 4 provides the result of the -statisisic for the null hypothesis that the mean response equals 0 (no importance). Columns 5 and 6 present the results from BBM (2005) survey, columns 7 and 8 present the results from BGHM (2005) survey. ****** and * denote a siggificant difference at he 1\%,5\%, and 10\% levels, respectively. 
A majority of respondents (79\%) consider current degree of financial leverage as one of the most important factors in dividend decision. $70 \%$ of the respondents view that maintaining consistency with their historic dividend policy (F16) as an important factor. The mean rating of this factor is 0.70 . That result is a supportive evidence for payout policy conservatism as Lintner (1956) suggested. But the evidence from the opinions of CFOs of Turkish listed firms is not as strong as the US evidence. $85 \%$ of respondents from the US firms agreed in that maintaining consistency with their historic dividend policy is important whereas $67 \%$ of European managers agreed in that.

The influence of institutional investors is somewhat important but not distinctive. $53 \%$ of the respondents agree that influence of institutional investors is important. The result is similar to European and the US firms. The mean rating of the managers of Turkish firms (0.34) is quiet lower than European and the US counterparts.

Personal tax status of shareholders is a very poor factor. Only $11 \%$ of respondents agree that tax status of shareholders is important when paying out dividends with a mean rating of -0.87 . The result implies that a great majority of the financial executives do not consider the tax status of the shareholders during payouts.

4.2 Dividend Patterns of Turkish Firms versus European and the US Peers

Table 4 shows survey responses about some dividend policy related statements ranked by the mean rating. The most agreed statement is that an optimal dividend policy strikes a balance between current dividends and future growth that maximizes stock price (S7). $84 \%$ of financial managers agree in this view with a mean rating of 0.97. That is one of the most agreed statements by the managers from European firms. Interestingly, $78 \%$ of the financial managers agree in the view that the dividend changes will have an impact on executive compensation (S10). Only $1 \%$ of the managers from European firms agree in this view whereas this is not applicable for the US survey. The mean rating is 0.84 . The reason behind this different result must be related to the corporate governance of Turkish firms because most of the Turkish listed firms are managed by insider ownership. The shareholders who hold control power and majority of shares are often at the top management in Turkish firms. Separation of management and ownership is not distinct to the extent of European firms.

$82 \%$ of the respondents believe in that dividend decisions convey information to investors (S4) with a 0.80 mean rating. The result is very similar to the evidence from the US managers. $80 \%$ of managers from the US firms agree in this view. This statement is not applicable in Europe survey. The result is consistent with signalling hypothesis. The managers believe in signalling effect of dividends. Yet, this is not an evidence of that they use dividends as signalling tools like most of signalling models imply.

A majority of the financial managers (82\%) agree in the view that dividends decrease the risk of the stock for shareholders (S14). This is an implication of what the classical bird-in-the-hand approach suggests. 60\% of European respondents think that dividends make a firm's stock less risky for shareholders. The opinions of the managers from the Turkish listed firms provide relatively stronger evidence to the bird-in-the-hand approach compared to the European managers. That result implies that the majority of Turkish managers think that dividend-paying firms attract risk-averse shareholders. 
Table 4: Responses to the Statements Related to Dividend Decisions

Column 1 lists each of the 18 statements rated by the respondents. Column 2 shows the percentage of responses of agree $(+1)$ and strongly agree $(+2)$. Column 3 shows the mean rating of each statement. Column 4 provides the result of the t-statistic for the null hypothesis that the mean response equals 0 (no importance). Columns 5 and 6 present the results from BBM (2005) survey, columns 7 and 8 present the results from BGHM (2005) survey. ***, ** and * denote a significant difference at the $1 \%, 5 \%$, and $10 \%$ levels, respectively.

\begin{tabular}{|c|c|c|c|c|c|c|c|}
\hline \multirow[b]{2}{*}{$\begin{array}{l}\text { Do these statements agree with your company's } \\
\text { dividend decisions? }\end{array}$} & \multicolumn{3}{|c|}{ Turkey } & \multicolumn{2}{|c|}{ Europe } & \multicolumn{2}{|c|}{ US } \\
\hline & $\begin{array}{l}\text { Agree } \\
\text { or str. } \\
\text { agree } \\
(\%)\end{array}$ & $\begin{array}{l}\mathrm{n}=38 \\
\text { Mean }\end{array}$ & $\begin{array}{l}\text { H0: } \\
\text { Avg. } \\
\text { Ratin } \\
\mathrm{g}=0\end{array}$ & $\begin{array}{l}\text { Agree } \\
\text { or str. } \\
\text { agree } \\
(\%)\end{array}$ & $\begin{array}{l}\mathrm{n}=93 \\
\text { Mean }\end{array}$ & $\begin{array}{l}\text { Agree } \\
\text { or str. } \\
\text { agree } \\
(\%)\end{array}$ & $\begin{array}{l}\mathrm{n}=256 \\
\text { Mean }\end{array}$ \\
\hline $\begin{array}{l}\text { An optimal dividend policy strikes a balance between } \\
\text { current dividends and future growth that maximizes } \\
\text { stock price (S7) }\end{array}$ & 84.21 & 0.97 & $* * *$ & 78.26 & 0.97 & $\mathrm{n} / \mathrm{a}$ & $\mathrm{n} / \mathrm{a}$ \\
\hline $\begin{array}{l}\text { Dividend changes will have an impact on executive } \\
\text { compensation (S10) }\end{array}$ & 78.38 & 0.84 & $* * *$ & 1.09 & -0.28 & $\mathrm{n} / \mathrm{a}$ & $\mathrm{n} / \mathrm{a}$ \\
\hline $\begin{array}{l}\text { Dividend decisions convey information about our } \\
\text { company to investors (S4) }\end{array}$ & 81.58 & 0.82 & $* * *$ & $\mathrm{n} / \mathrm{a}$ & $\mathrm{n} / \mathrm{a}$ & 80.00 & 1.00 \\
\hline $\begin{array}{l}\text { Dividends make a firm's stock less risky for } \\
\text { shareholders (vs. retaining earnings) (S14) }\end{array}$ & 81.58 & 0.82 & $* * *$ & 60.22 & 0.56 & 37.50 & 0.00 \\
\hline $\begin{array}{l}\text { A firm should view cash dividends as a residual after } \\
\text { financing desired investments from earnings (S9) }\end{array}$ & 75.68 & 0.81 & $* * *$ & 31.87 & 0.10 & $\mathrm{n} / \mathrm{a}$ & $\mathrm{n} / \mathrm{a}$ \\
\hline $\begin{array}{l}\text { A firm's dividend policy generally affects its cost of } \\
\text { capital (S8) }\end{array}$ & 70.27 & 0.78 & $* * *$ & 36.96 & 0.25 & $\mathrm{n} / \mathrm{a}$ & $\mathrm{n} / \mathrm{a}$ \\
\hline $\begin{array}{l}\text { We make dividend decisions after our investment plans } \\
\text { are determined (S1) }\end{array}$ & 73.68 & 0.68 & $* * *$ & 44.57 & 0.38 & 33.10 & -0.30 \\
\hline $\begin{array}{l}\text { Dividends are as important now to the valuation of } \\
\text { common stocks as they were } 15 \text { years ago (S3) }\end{array}$ & 65.79 & 0.61 & $* * *$ & 53.33 & 0.57 & 40.30 & 0.03 \\
\hline $\begin{array}{l}\text { A firm should set a target dividend payout ratio and } \\
\text { adjust its current payout toward the target (S13) }\end{array}$ & 71.05 & 0.58 & $* *$ & 54.35 & 0.48 & $\mathrm{n} / \mathrm{a}$ & $\mathrm{n} / \mathrm{a}$ \\
\hline We try to avoid reducing dividends per share (S2) & 60.53 & 0.47 & $* * *$ & 82.80 & 1.22 & 93.80 & 1.57 \\
\hline $\begin{array}{l}\text { Investors prefer that a firm retains funds over paying } \\
\text { dividends because of the way capital gains are taxed as } \\
\text { compared with dividends (S15) }\end{array}$ & 57.89 & 0.45 & $* * *$ & 10.87 & -0.17 & $\mathrm{n} / \mathrm{a}$ & $\mathrm{n} / \mathrm{a}$ \\
\hline $\begin{array}{l}\text { Paying dividends is a priority (many financial } \\
\text { decisions are secondary compared with dividends (S5) }\end{array}$ & 50.00 & 0.42 & $* *$ & 44.09 & 0.25 & $\mathrm{n} / \mathrm{a}$ & $\mathrm{n} / \mathrm{a}$ \\
\hline $\begin{array}{l}\text { Investors invest in firms whose dividend policies } \\
\text { complement their particular tax circumstances (S16) }\end{array}$ & 47.37 & 0.26 & & 26.88 & 0.10 & $\mathrm{n} / \mathrm{a}$ & $\mathrm{n} / \mathrm{a}$ \\
\hline $\begin{array}{l}\text { Dividend changes generally lag behind earnings } \\
\text { changes (S6) }\end{array}$ & 44.74 & 0.08 & & 34.78 & 0.20 & $\mathrm{n} / \mathrm{a}$ & $\mathrm{n} / \mathrm{a}$ \\
\hline $\begin{array}{l}\text { We pay dividends to show that our stock is valuable } \\
\text { enough that investors buy it even though we have to } \\
\text { pay relatively costly dividend taxes (S18) }\end{array}$ & 31.58 & -0.11 & & 11.83 & -0.16 & 16.60 & -0.65 \\
\hline $\begin{array}{l}\text { Do these statements agree with your company's } \\
\text { dividend decisions? }\end{array}$ & $\begin{array}{c}\text { Agree } \\
\text { or str. } \\
\text { agree } \\
(\%)\end{array}$ & $\begin{array}{l}\mathrm{n}=38 \\
\text { Mean }\end{array}$ & $\begin{array}{c}\text { H0: } \\
\text { Avg. } \\
\text { Ratin } \\
\mathrm{g}=0\end{array}$ & $\begin{array}{c}\text { Agree } \\
\text { or str. } \\
\text { agree } \\
(\%)\end{array}$ & $\begin{array}{l}\mathrm{n}=93 \\
\text { Mean }\end{array}$ & $\begin{array}{c}\text { Agree } \\
\text { or str. } \\
\text { agree } \\
(\%)\end{array}$ & $\begin{array}{l}\mathrm{n}=256 \\
\text { Mean }\end{array}$ \\
\hline $\begin{array}{l}\text { Investors generally prefer cash dividends today to } \\
\text { uncertain future price appreciation (S17) }\end{array}$ & 23.68 & -0.13 & & 53.76 & 0.49 & $\mathrm{n} / \mathrm{a}$ & $\mathrm{n} / \mathrm{a}$ \\
\hline $\begin{array}{l}\text { We try to maintain a smooth dividend stream from } \\
\text { year-to-year (S12) }\end{array}$ & 13.16 & -0.95 & $* * *$ & 77.42 & 1.09 & 89.60 & 1.30 \\
\hline $\begin{array}{l}\text { We pay dividends to show that our firm is strong } \\
\text { enough to pass up some profitable investments (S11) }\end{array}$ & 13.16 & -0.95 & $* * *$ & 18.48 & -0.05 & 9.00 & -1.01 \\
\hline
\end{tabular}

Source: Author 
$76 \%$ of respondents agree that a firm should view cash dividends as a residual after financing desired investments from earnings (S9) with a mean rating of 0.81 . The survey result indicates that a majority of the financial managers of Turkish listed firms view the cash dividends as residual cash flows.

$74 \%$ of the respondents agree that they make dividend decisions after their investment plans are determined (S1). On a scale from -2 (strongly disagree) to +2 (strongly agree), the mean rating is 0.68 . The result implies that investing decisions come before financing or dividend payout decisions. The responses to (S1) are consistent with the result of the statement (S9). This result supports the argument of residual cash flow. $45 \%$ of European respondents and $34 \%$ of the respondents from the US firms agree in that statement. Therefore, the survey results on Turkish listed firms provide evidence for free cash flow theory unlike the European and US firms.

Trying to avoid reducing dividend per share (S2; mean rating: 0.47 ) is not a relatively common view for the respondents from Turkish listed firms whereas it is the most ranked statement for European and the US firms. $61 \%$ of the respondents agree that they try to avoid reducing dividend per share while $94 \%$ of respondent firms from the US and $83 \%$ of European respondents agree in that statement. This result implies that a great majority of European and the US financial managers view dividend policy as a tool to manage DPS much more than Turkish managers.

Only $13 \%$ of the respondents agree that they try to maintain a smooth dividend stream from year-to-year
(S12; mean rating: -0.95). Dividend smoothing refers to distributing a fixed dividend amount over time. A significant majority of both European and the US managers ( $77 \%$ of European respondents and $90 \%$ of the US respondents) agree in that statement unlike Turkish managers. This is one of the important findings in the survey. Lintner (1956) suggests that firms smooth dividends over years. The empirical surveys conducted more than half a century ago and recent studies in Europe and the US still provide strong evidence for dividend smoothing. Nevertheless the responses from Turkish listed firms do not provide any evidence for dividend smoothing.

Dividend targeting refers to a specific proportion of a firm's earnings that firms would like to pay in dividends. Figure 1 exhibits the responses to what the firms target when they make dividend decisions. $51 \%$ of respondents report that they use dividend yield as dividend targeting. $19 \%$ of the respondents target payout ratio whereas $16 \%$ do not target at all. The results are very different when the responses from Turkish listed firms are compared to European and the US counterparts. DPS level (35\%) is reported as the target used at most in dividend decision of respondents from European firms whereas $8 \%$ of respondents from Turkish listed firms report they use DPS level. Other than DPS level, European respondents use different dividend targets, such as growth in dividends per share $(23 \%)$, and dividend yield $(11 \%)$. The results of the respondents from the US are similar to European counterparts, but much different from the results of Turkish listed firms.

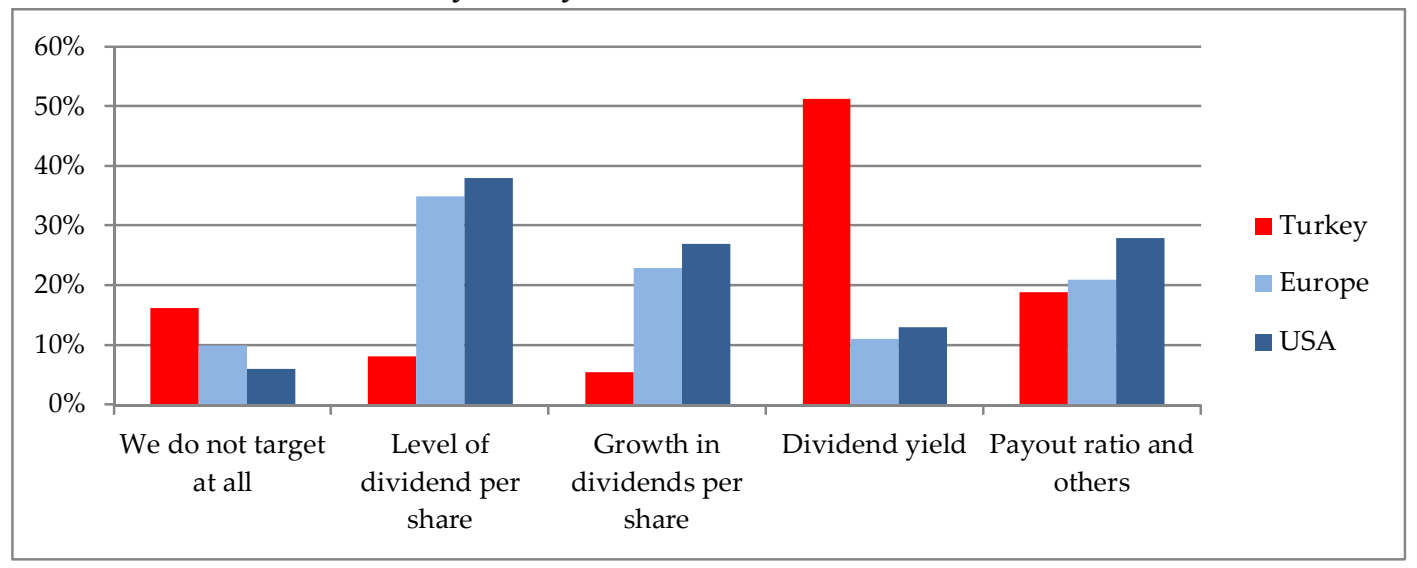

Figure 1: Responses to the Question: What do you target when you make dividend decisions?

The main hypothesis is that the opinions of the managers of Turkish listed firms on dividend policy are similar to European peers. Nonparametric Wilcoxon signed-rank test is used to test whether there are differences between the opinions of Turkish listed firms' managers and European peers on dividend policy. The tests are performed on the mean ratings of the responses to the factors influencing dividends to test the hypothesis $\mathrm{H}_{1 \mathrm{a}}$ and on the mean ratings of agreement level in the statements related to dividend 
policy to test the hypothesis $\mathrm{H}_{1 \mathrm{~b}}$ separately. The test results provide mixed evidence. The values of test statistics of the mean ratings of the factors influencing dividend payout decisions are significant at the $5 \%$ level whereas those of the statements related to dividend decisions are not significant at the $5 \%$ level. Therefore, the hypothesis $\mathrm{H}_{1 \mathrm{a}}$ is rejected whereas the hypothesis $\mathrm{H}_{1 \mathrm{~b}}$ is accepted. That means that the factors influencing the dividend decisions of the Turkish and European firms are not similar based on the opinions of their financial managers when their opinions on the statements related to dividend decisions are similar. Thus, there is not sufficient evidence to accept the similarity of Turkish and European firms' dividend policies.

\section{Share Repurchases}

Share repurchase is a fresh issue for Turkish firms because acquiring a company's own stocks has been legally permitted recently. The respondents were asked their opinions about share repurchase at the commencement of the new practice. The responses exhibit that the majority of managers are not much interested in share repurchases. Nevertheless if their firms were to repurchase the shares, the responses show that the most important factor would be the market price of the firm's stock.

Table 5 shows the responses to the factors that affect share repurchase decisions. $68 \%$ of the respondents report that market price of firm's share is important in repurchase decision with a mean rating of 0.84 on a scale from $(-2)$ to $(+2)$. The second ranked factor in repurchase decision is merger and acquisition strategy. $57 \%$ of the managers from respondent firms think that merger and acquisition strategy (F3) and having extra cash assets relative to the desired cash holdings (F6) are an important factor influencing share repurchases decision. The mean ratings are 0.41 and 0.38 , respectively. Sustainable change in earnings is the next factor with a mean rating of 0.35 . $51 \%$ of respondents think that sustainable change in earnings is an important factor in share repurchases decision.

The most ranked factor influencing repurchase decision in both BBM (2005) and BGHM (2005) surveys is the market price of the stock like it is the case in our survey. The mean ratings of the respondents from European and the US firms are much higher than the mean rating of Turkish respondents; 1.38 and 1.30, respectively. The second ranked factor in repurchase decision is the availability of investment opportunities (F2) with mean ratings of 1.14 and 1.10 for European and the US managers, respectively. On the contrary, the mean rating for the factor (F2) is -0.51 in our survey. The result implies that the availability of investment opportunities is not an important factor for share repurchases decision of Turkish firms unlike European and the US peers. In European and the US rankings, the next important factors are merger and acquisition strategy, and having excess cash assets relative to the desired cash holdings. These results are relatively similar to Turkish respondents. Nevertheless the mean ratings of European and the US firms are apparently much higher than Turkish firms. This shows that most Turkish managers do not find important to repurchase the firm's own shares, yet.

A nonparametric test is used to test the hypothesis $\mathrm{H}_{2}$ about share repurchase decision. The equality of the paired relative rankings of all factors across the two groups is tested by Wilcoxon signed-rank test. The results of test statistics are significant at the 5\% level. Therefore, the hypothesis is rejected. According to test results, there is sufficient evidence to suggest that there are differences between the opinions of the managers from Turkish listed firms and European peers on the factors influencing share repurchase decision.

Figure 2 exhibits a comparison of the factors influencing share repurchases and dividend payouts. The perceptions of managers on the factors of share repurchases versus dividend payouts give very different results. The ratings show that financial managers do not view repurchases as substitutes for dividends because the motives on share repurchases and dividend decisions are different. However having extra liquid assets relative to desired cash holdings has an importance on dividend payout and repurchase decisions nearly at the same extent. About half of the respondents agree that having excess liquid assets more than desired is an important factor both on share repurchases and dividend payouts. $35 \%$ of respondents agree that repurchases reduce cash and reducing cash disciplines the firm to make efficient decisions whereas $24 \%$ agree that paying out dividends reduces cash, and disciplines the firm to make efficient decisions. These results suggest that a firm with excess cash holdings is more likely to repurchase than paying out dividends. 


\section{Narman Kuzucu /International Journal of Research in Business and Social Science \\ Vol 4, No 2, 2015 ISSN: $2147-4478$}

Table 5: Responses to the Factors Influencing Share Repurchase Decisions

Column 1 lists each of the 15 factors rated by the respondents. Column 2 shows the percentage of responses of important $(+1)$ and very important $(+2)$. Column 3 shows the mean rating of each factor. Column 4 provides the result of thet -statistic for the null hypothesis that the mean response equals 0 (no importance). Columns 5 and 6 present the results from BBM (2005), columns 7 and 8 present the results from BGHM (2005). ****, **and * denote a siginificant difference at the 1\%,5\%, and 10\% levels, respectively.

\begin{tabular}{|c|c|c|c|c|c|c|c|}
\hline \multirow[b]{2}{*}{ How important would be the following factors if your company were to repurchase shares? } & \multicolumn{4}{|c|}{ Turkey } & Europe & \multicolumn{2}{|c|}{ US } \\
\hline & $\begin{array}{l}\text { Imp. or } \\
\text { Very } \\
\text { Imp. } \\
(\%)\end{array}$ & $\begin{array}{l}\mathrm{n}=38 \\
\text { Mean }\end{array}$ & $\begin{array}{c}\text { HO: } \\
\text { Average } \\
\text { Rating=0 }\end{array}$ & $\begin{array}{l}\text { Imp. } \\
\text { of } \\
\text { Very } \\
\text { Imp. } \\
(\%) \\
\end{array}$ & $\begin{array}{l}\mathrm{n}=93 \\
\text { Mean }\end{array}$ & $\begin{array}{l}\text { Imp. or } \\
\text { Very } \\
\text { Imp. } \\
(\%) \\
\end{array}$ & $\begin{array}{l}\mathrm{n}=256 \\
\text { Mean }\end{array}$ \\
\hline Market price of our stock (if our stock is a good investment relative to its thue value) (F1) & 67.57 & 0.84 & $* * *$ & 90.11 & 1.38 & 86.40 & 1.30 \\
\hline Merger and acquisition strategy (external stocks for grovwh transactions) (F3) & 56.76 & 0.41 & *** & 64.44 & 0.80 & 72.30 & 0.90 \\
\hline Having extra cash/liquid assets relative to our desired cash holdings (F6) & 56.76 & 0.38 & *** & 64.04 & 0.75 & 61.90 & 0.70 \\
\hline A sustainable change in earnings (F5) & 51.35 & 0.35 & *** & 46.67 & 0.39 & 65.20 & 0.70 \\
\hline Stability of future earnings (F4) & 45.95 & 0.32 & ** & 50.56 & 0.46 & 65.60 & 0.70 \\
\hline Offsetting the dilutionary effect of stock option plans or other stock programs (F10) & 36.11 & 0.11 & * & 29.21 & 0.19 & 67.10 & 0.80 \\
\hline The company wants to cancel share (F15) & 43.24 & 0.11 & & 20.00 & -0.02 & $n / a$ & $n / a$ \\
\hline Repurchasing shares to reduce cash, thereby disciplining our firm to make efficient decisions (F8) & 35.14 & 0.03 & & 27.78 & 0.08 & 20.30 & -0.60 \\
\hline Increasing earnings per share ( $(\mathrm{Fg})$ & 19.44 & -0.42 & ** & 51.69 & 0.57 & 75.00 & 0.90 \\
\hline The influence of our institutional shareholders (F7) & 21.62 & -0.46 & *** & 30.00 & 0.08 & 51.90 & 0.40 \\
\hline The availability of good investment opportunities for our firm to pursue (F2) & 21.62 & -0.51 & 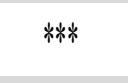 & 77.78 & 1.14 & 80.30 & 1.10 \\
\hline A temporary change in earrings $(\mathrm{F} 12)$ & 11.11 & -0.67 & **** & 12.22 & -0.18 & 35.00 & -0.10 \\
\hline To reinforce the control of major shareholders (F11) & 5.56 & -0.83 & *** & 8.89 & -0.13 & $n / a$ & n/a \\
\hline Personal taxes of our stockholders (F14) & 5.56 & -1.08 & **** & 14.44 & -0.10 & 29.10 & -0.30 \\
\hline Repurchass shares is better alternative than dividends to give cash to investors ( $F 13$ ) & 2.78 & -1.31 & $* * *$ & 18.89 & 0.09 & $n / a$ & $n / a$ \\
\hline
\end{tabular}




\section{Narman Kuzzucu /nternational Journal of Research in Business and Social Science \\ Vol 4, No 2, 2015 ISSN: 2147-4478}

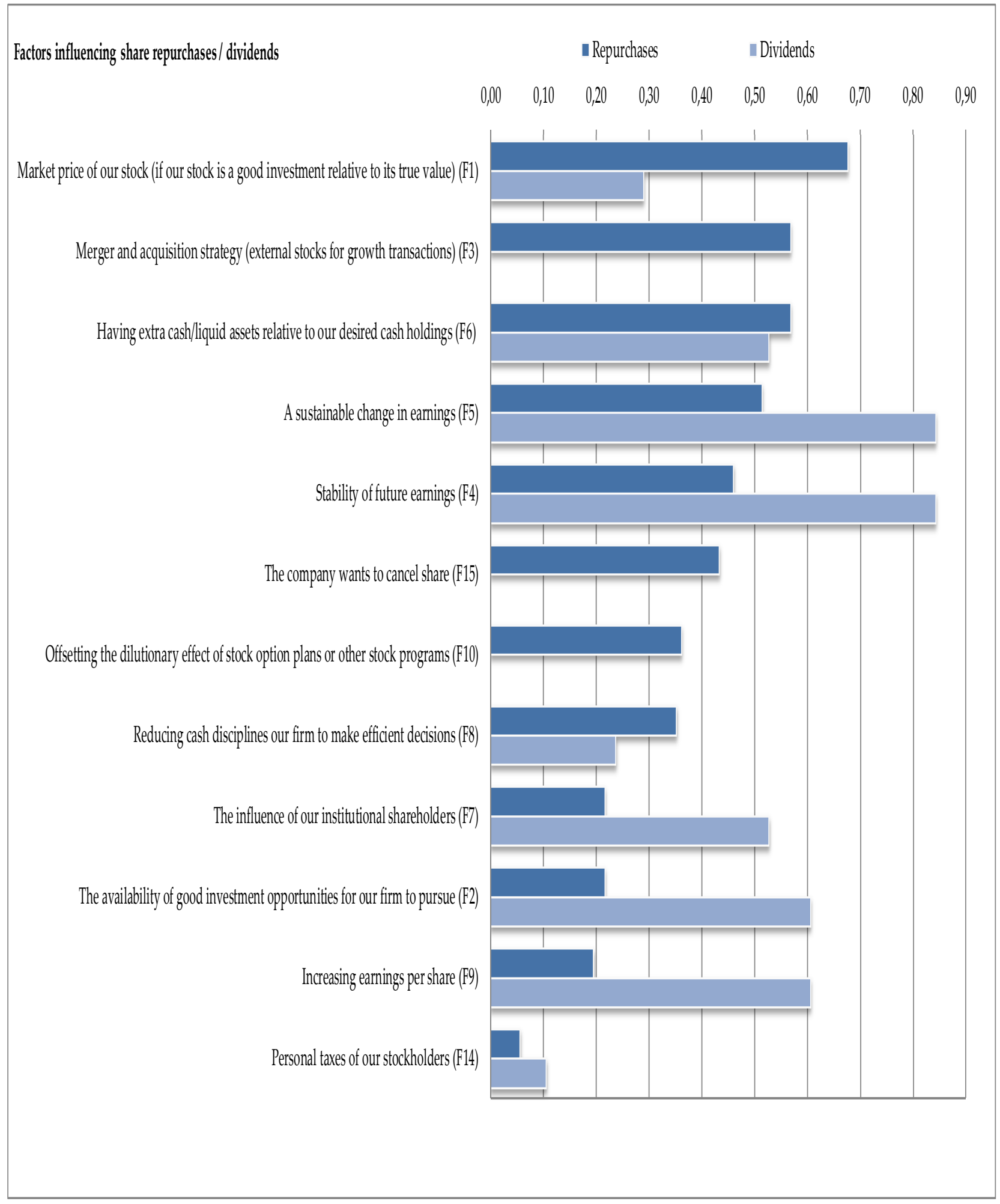

Figure 2: The Most Important Factors for Repurchaseses versus Dividend Payouts

Note: The figure shows the percentages of respondents who agree in that the related factor is important or very important in dividend payouts/ share repurrchase decisions.

Peer-reviewed Academic Journal published by SSBFNET with respect to copyright holders. 
$68 \%$ of the respondents agree that the market price of the firm's share is an important factor in repurchase decision whereas $29 \%$ of the respondents view the market price of the firm's share is an important factor in dividend payout decision. Ceteris paribus, a firm experiencing undervaluation of its share price is more likely to decide share repurchase than dividend payout. Additionally, institutional investors are influential more on dividend payouts rather than repurchases.

Figure 3 shows the responses to the share repurchase definition. $38 \%$ of the respondents think share repurchase is a tool for financial flexibility. $22 \%$ of the respondents report that firms may repurchase shares for the purpose of managing EPS ratio. $16 \%$ of the managers have no idea while $16 \%$ of the managers state other opinions in the open-ended choice. Other opinions are generally affecting or manipulating market price of the stock. Only $8 \%$ of the respondents think share repurchase is an alternative to paying dividends.

$40 \%$ of European respondents think share repurchase is a tool for flexibility. This is a very similar result to Turkish respondents. Nevertheless 29\% of European respondents think that share repurchase is an alternative to dividend payouts whereas it is a very poor alternative to dividend payouts in the opinions of the managers of Turkish listed firms.

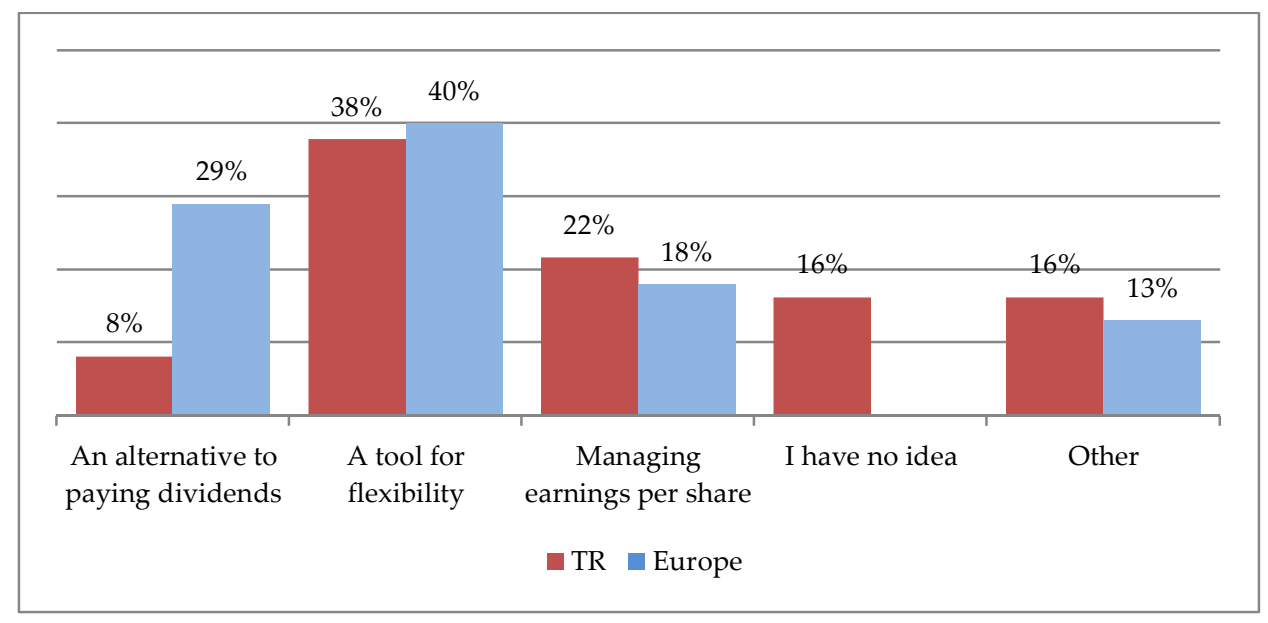

Figure 3: Responses to the Question: In your opinion, share repurchase is ...

Figure 4 shows the responses to the question whether the financial managers think Turkish firms will repurchase shares. $32 \%$ of the respondents think they may repurchase company's shares. The most common response was "probably no" (37\%). 21\% of the managers are undecided about share repurchases. 5\% of the respondents report they will definitely repurchase shares. The ratio of the ones who think they will definitely not repurchase shares is $5 \%$ in the meantime. In a different approach, $42 \%$ of the respondents report that they think their firms will not repurchase shares while $37 \%$ of the respondents think that they will.

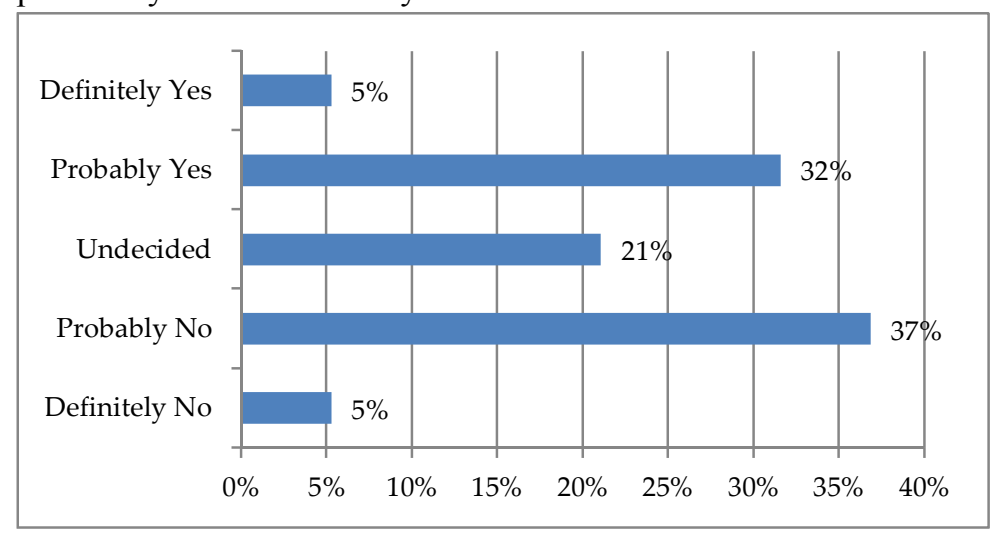

Figure 4: The Responses to the Question: Do you think your company will repurchase shares? 


\section{Cross-Sectional Regression Results}

The cross-sectional analysis shows differences between managers' responses, based on the firm's characteristics such as size, industry and others. It is investigated whether firm specific factors affect the opinions of managers on dividend policy, by running a cross-sectional logit regression model. Several firm characteristic variables are used to proxy these effects on dividend policy. For the response rank of each factor and each statement in the survey, following cross-sectional regression model is established.

$$
\begin{aligned}
\text { [Response Rank }]_{\mathrm{i}} & \left.\alpha+\beta_{1} \text { [Size }\right]+\beta_{2} \text { [Industry] } \\
& +\beta_{3}[\text { ForeignSales }] \\
& +\beta_{4}[\text { ForeignShares }] \\
& +\beta_{5}[\text { FloatingRate }] \\
& +\beta_{6}[\text { Ownership }] \\
& +\beta_{7}[\text { PayoutRatio }] \\
& +\beta_{8}[\text { Leverage }]+\beta_{9}[\mathrm{P} / \mathrm{B}] \\
& ++\beta_{10}[\mathrm{P} / \mathrm{E}]+\beta_{11}[\mathrm{EPS}]+\epsilon_{\mathrm{i}}
\end{aligned}
$$

where [Response Rank] $\mathrm{j}$ is the rating of respondent firm i, and varies between $(-2)$ to $(+2)$ which represents not important to very important. We try to estimate the relative importance of factors and the opinions of financial managers based on firm specific variables. Firm size (Size) is measured by the natural $\log$ of the sales revenue. Industry (Ind) is denoted as manufacturing or not, and ownership (Own) is designated by family control in the analysis. Foreign sales (Exp) indicate the proportion of foreign sales to the total sales revenue of a respondent firm. Foreign shares (For) variable is the ratio of shares of a firm held by foreigners. Leverage is (DA) measured by the ratio of debts to total assets.

Ramsey's RESET is performed to test some probable problems including omitted variables and misspecification errors, and provide robustness to the model. The results show that the regression models do not include misspecification errors.

\section{The Relationships between the Firm Characteristics and the Dividend Payouts}

The cross-sectional tests are used to determine the level of significance of the differences in the level of agreement according to the characteristics of respondent firms. The results indicate that firm specific variables have little significance on the factors of dividend decision while some are insignificant on the variation in the rankings of dividend policy factors. No firm characteristic is significant in the variation of the rankings of 6 of 16 factors (Table 3; F6, F7, F9, F13, F15 and F16).
Size is the most common firm specific determinant in the variation of responses. the responses of the managers of small / large firms differ significantly on 5 of 16 factors (F1, F2, F3, F8 and F12). Larger firms are less likely to agree on the effect of sustainable change in earnings, and stability and level of future earnings on dividend decisions. Foreign ownership is significant on the variation in the rankings of 4 of 16 factors (F3, F8, F12 and F14). The managers of the firms with more foreign ownership are more likely to agree on the importance of F3.

Smoothing dividends: Ownership and size are significant in the variation in the rankings of the S12 which is "we try to maintain a smooth dividend stream from year-to-year." Family controlled firms care more about smoothing dividends whereas larger firms care less about smoothing dividends. These variables explain about 28 percent of the cross-sectional variation in the ranking.

Targeting payout ratio: Payout ratio, family control, foreign shares, size and price-to-book ratio are significant in the variation in the rankings in the agreement level of informational content of dividends. Payout ratio is significant at the $1 \%$ level and negatively related to the variation in the rankings of target payout ratio. That means firms with higher payout ratios care less about targeting dividends. Family control and price-to-book ratio are positively related to targeting. Foreign shares are negatively related to targeting policy. The results suggest that family controlled and/or high market value firms care more about dividend targeting whereas firms with higher foreign ownership and/or higher payout ratios care less about dividend targeting. These variables explain about 67 percent of the cross-sectional variation in the ranking.

Informational content of dividends: The crosssectional analysis indicates that firm specific factors; industry, payout ratio, size and price-to-book ratio are significant in the variation in the rankings in the agreement level of informational content of dividends. These variables explain about 68 percent of the crosssectional variation in the ranking. The managers from manufacturing firms and/or the firms with higher payout ratios are more likely to report they believe in the informational content of dividends.

Agency costs and self-imposed discipline by payout policy: Foreign ownership and foreign sales are related to the variation in the ranking of this factor. Accordingly, firms with higher foreign sales in relative to their total sales are more likely to think that 
paying dividends reduces cash and disciplines their firms to make efficient decisions. Foreign ownership is negatively related to this factor. The managers from the firms with more foreign ownership are less likely to agree in this factor.

\section{The Relationships between the Firm Characteristics and the Factors Influencing Share Repurchase Decisions}

The variations in firm characteristics have limited significance in the variations of rankings in share repurchase determinants. No firm characteristic differs significantly in 5 of 15 share repurchase factors (Table 5; F4, F5, F9, F12 and F14). This result suggests that the variations in firm characteristics such as size, industry, profitability, leverage and others have little effect on the factors of share repurchase decision. However the most significant variable among the firm-specific variables explaining the ranking of share repurchase determinants is the payout ratio of the respondent firms.

Market price of the stock (F1) is the most important factor which affects share repurchase decision according to the survey results. The cross-sectional analysis indicates that the firms with higher payout ratios and/or lower $\mathrm{P} / \mathrm{E}$ ratios are more likely to agree on that market price of the stock is important on share repurchase decision. These two firm specific factors explain about 50 percent of the cross-sectional variation in the ranking of the stock price factor in share repurchases.

The cross-sectional results presented here should be interpreted with some caution because of potential biases and measurement problems that are inherent in survey researches. The survey has a relatively narrow sample size and limited number of respondents despite an acceptable response rate. That weakens the statistical power of the test results.

\section{Conclusion}

The corporate dividend payout policy of Turkish listed firms is investigated in this research. The study uses survey methodology to examine the opinions of corporate managers on the dividend policy of their firms. The opinions of financial managers are crucial on dividends because they take important roles in corporate financing decisions.

The survey results show that majority of Lintner's findings (1956) obtained more than half a century ago are valid at BIST today whereas some are not supported. Earnings level and the stability of future earnings are the most important factors influencing dividend decisions as Lintner suggested. Majority of financial managers report that they try to maintain the consistency with the historical level of dividends. This result is consistent with Lintner. Nevertheless, they do not agree in smoothing dividends as Lintner proposed.

The main hypothesis of the survey is the views of Turkish and European firms' managers on dividend payout policy are influenced by similar factors. Wilcoxon signed-rank test is used to test whether there are differences between the opinions of two groups. The opinions of the European managers are based on the findings of the survey study of Bancel et al. (2005). The test results provide mixed evidence. The test results suggest that the opinions of the Turkish firms' managers and European peers on the factors influencing the dividend decisions are not similar when their opinions on the statements related to dividend decisions are similar. Thus, there is not sufficient evidence to accept the hypothesis.

Share repurchase is a fresh issue in Turkish share market. The survey research results presented in this study shed light on that under which specific conditions Turkish listed firms are more likely to decide share repurchase or dividend payouts. Market price of a firm's share is the most important factor in share repurchase decision as it is such like in the survey results of Brav et al. (2005) and Bancel et al. (2005) for US firms and European firms. This study is one of the first empirical studies on share repurchase decision of Turkish listed firms.

The research contributes to the dividend literature by examining the evidence on Turkish listed firms' dividend behaviours on BIST which is an internationalized emerging stock market. The determinants of dividend decisions and the rationale behind the dividend policy are investigated through a survey on the opinions of finance executives. The results provide valuable evidence for the understanding of corporate dividend behaviours of Turkish firms.

\section{Acknowledgement}

This paper is extracted from a part of the doctoral dissertation of the author at Marmara University, School of Business Administration, Istanbul, Turkey. The author submits special thanks to Prof. Dr. A. Osman Gurbuz from Istanbul Commerce University and Assoc. Prof. Dr. Emin Avc1 from Marmara 
University for their supervision and guidance through this research

\section{References}

Baker, H. K., and G.E. Powell. (1999). How corporate managers view dividend policy? Quarterly Journal of Business and Economics, 38.2, 17-35.

Baker, H. K., and G.E. Powell. (2000). Determinants of Corporate Dividend Policy: A Survey of NYSE Firms. Financial Practice and Education, 10.1, 29-40.

Baker, H. K., G. E. Farrelly, and R. B. Edelman. (1985). A Survey of Management Views on Dividend Policy. Financial Management, 14.3, 78-84.

Baker, H. K., G.E. Powell and E.T. Veit. (2002). Revisiting managerial perspectives on dividend policy. Journal of Economics and Finance, 26-3. 267-283.

Baker, H. K., J. C. Singleton and E. T. Veit. (2011). Survey Research in Corporate Finance: Bridging the Gap between Theory and Practice. Oxford: Oxford University Press.

Baker, H. K., S. Dutta and S. Saadi. (2008). Impact of financial and multinational operations on manager perceptions of dividends. Global Finance Journal, 19.2, 171-186.

Baker, M., and J. Wurgler. (2004). Appearing and disappearing dividends: The link to catering incentives. Journal of Financial Economics, 73, 271-288.

Bancel, F., N. Bhattacharyya and U.R. Mittoo. (2005). Cross-country determinants of payout policy: A survey of European firms. SSRN Working Paper, available at SSRN: http://ssrn.com/abstract $=683111$.

Bhattacharya, S. (1979). Imperfect Information, Dividend Policy, and the Bird in the Hand Fallacy. Bell Journal of Economics, 10, 259-270.

Brav, A., J.R. Graham, C.R. Harvey and R. Michaely. (2005). Payout policy in the 21 st century. Journal of Financial Economics, 77, 483-527.

Brennan, M. J. (1970). Taxes, market valuation and corporate financial policy. National Tax Journal, 23, 417-427.

Da Silva, C.L., M. Goergen and L. Renneboog (2004). Dividend Policy and Corporate Governance. Oxford: Oxford University Press.

DeAngelo, H., L. DeAngelo and D.J. Skinner. (2004). Are dividends disappearing? Dividend concentration and the consolidation of earnings. Journal of Financial Economics, 72.3, 425-456.

Denis, D.J. and I. Osobov. (2008). Why Do Firms Pay Dividends? International Evidence on the Determinants of Dividend Policy. Journal of Financial Economics, 89.1, 62-82.

Dong, M., C. Robinson, and C. Veld. (2005). Why Individual Investors Want Dividends. Journal of Corporate Finance, 12.1, 121-158.
Elton, E. J., and M. J. Gruber. (1970). Marginal Stockholder Tax Rates and the Clientele Effect. Review of Economics and Statistics, 52.1, 68-74.

Fama, E. F. and K. R. French. (2001). Disappearing dividends: Changing firm characteristics or lower propensity to pay? Journal of Financial Economics, 60, 3-43.

Graham, J. R., and A. Kumar. (2006). Do Dividend Clienteles Exist? Dividend Preferences of Retail Investors. Journal of Finance, 61, 1305-1336.

Grinstein, Y., and R. Michaely. (2005). Institutional Holdings and Payout Policy. Journal of Finance, 60.3, 1389-1426.

Jensen, M. C., and W. H. Meckling. (1976). Theory of the firm: Managerial behaviour, agency costs and ownership structure. Journal of Financial Economics, 3, 305-360.

La Porta, R., F. Lopez-De-Silanes, A. Shleifer and R. Vishny. (2000). Agency problems and dividend policy around the world. Journal of Finance, 55, $1-33$.

Lintner, J. (1956). Distribution of incomes of corporations among dividends, retained earnings and taxes. American Economics Review, 6, 97113.

Miller, M. H., and F. Modigliani. (1961). Dividend policy, growth, and the valuation of shares. Journal of Business, 34, 411-433.

Miller, M. H., and K. Rock. (1985). Dividend Policy under Asymmetric Information. Journal of Finance, 40.4, 1031-1051.

Miller, M. H., and M. S. Scholes. (1978). Dividends and Taxes. Journal of Financial Economics, 6, 333-364.

Pruitt, S. W. and L. J. Gitman. (1991). The Interactions Between the Investment, Financing and Dividend Decisions of Major US Firms. Financial Review, 26.3, 409-430.

Ross, S. A. (1977). The Determination of Financial Structure: The Incentive-Signalling Approach. Bell Journal of Economics, 8.1, 23-40.

Shefrin, H., and M. Statman. (1984). Explaining Investor Preference for Cash Dividends. Journal of Financial Economics, 13, 253-282.

Shefrin, H., and R. Thaler. (1988). The Behavioural Life Cycle Hypothesis. Economic Inquiry, 26.4, 609-643. 